American J. of Engineering and Applied Sciences 1 (4): 393-398, 2008

ISSN 1941-7020

(C) 2008 Science Publications

\title{
Aerobic Biostabilization of Old MSW Landfills
}

\author{
M.C. Zanetti \\ Dipartimento di Ingegneria del Territorio, Politecnico di Torino, \\ dell'Ambiente e delle Geotecnologie, 10129 Turin, Italy
}

\begin{abstract}
Many years after the end of the cultivation phase, landfills may generate intense odours, toxic and explosive gases and heavily-polluted leachate. A wide-spreading trend in the management of MSW landfills is represented by the forced aeration of wastes in order to achieve the stabilization, reducing the negative environmental impact of uncontrolled sites (old landfills which can be definitely considered as contaminated sites) and the management costs of controlled and working facilities. One of the most interesting challenges is the in situ waste aerobic stabilization, obtained by insufflating air into the wastes. The aerobic metabolism is energetically convenient in comparison with the anaerobic one, it is characterized by a higher degradation rate and a temperature increase (like in the compost production). In order to obtain an aerobic biostabilization of waste in landfills, several air injection systems have been developed and applied in the last years, like Biopuster ${ }^{\odot}$ or AEROflott ${ }^{\circledR}$ patented systems. The feasibility of the application of in situ biostabilization must be evaluated by means of different tests, in order to evaluate the main characteristics of the wastes. The main parameters to be evaluated are the biological stability and the air permeability of the wastes. In March 2006, the biological stability of the wastes located in the Trinitapoli Landfill, Italy, has been evaluated by the Politecnico di Torino. Black Index Test and Static Respirometric Index Test have been performed in the laboratories of the Politecnico. On the basis of the obtained results, the potential biogas production from the examined landfill was estimated together with the potential volume reduction.
\end{abstract}

Keywords: Biological stabilization, laboratory tests, volume reduction

\section{INTRODUCTION}

MSW landfills are usually characterized by five different phases: a first, short-lasting aerobic phase and four anaerobic phases (Fig. 1). During the first aerobic phase (Initial Phase), which lasts for a very short period, organic substances are biodegradated by the action of anaerobic microorganisms that consume oxygen, the results of this biodegradation process are essentially $\mathrm{CO}_{2}, \mathrm{H}_{2} \mathrm{O}$ and partially degradated organic substances:

$$
\mathrm{CH}_{\mathrm{a}} \mathrm{O}_{\mathrm{b}} \mathrm{N}_{\mathrm{c}}+1 / 4(4 \mathrm{a}-2 \mathrm{~b}-3 \mathrm{c}) \mathrm{O}_{2} \rightarrow \mathrm{CO}_{2}+1 / 2(\mathrm{a}-3 \mathrm{c}) \mathrm{H}_{2} \mathrm{O}+\mathrm{cNH}_{3}
$$

The aerobic biodegradation is much faster than the anaerobic one. In the second phase (Transition Phase), the lack of oxygen into the wastes leads to a switch from aerobic to anaerobic conditions into the landfill, which are characterized by the action of anaerobic microorganisms that do not consume oxygen for cellular respiration, but use other substances, like nitrates or sulphates, as electrons acceptors. This phase is characterized by an increase of Total Volatile Acids (TVA) and COD value in the leachate.

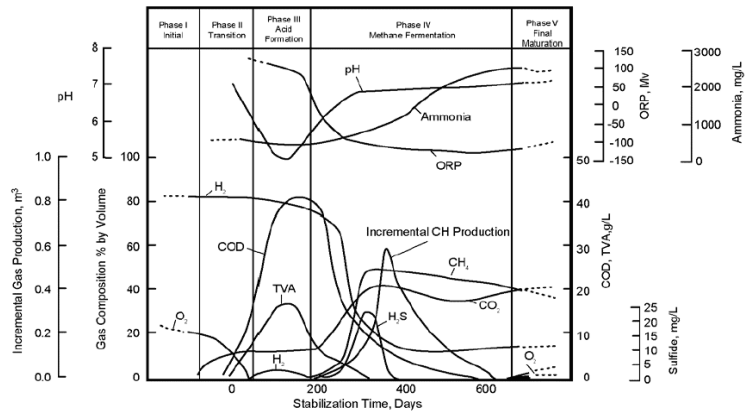

Fig. 1: Landfill stabilization phases

In the third phase (Acid Phase), TVA formation leads to an increase of $\mathrm{pH}$ values and to the mobilization of metals. Moreover, COD reaches a maximum value in this phase. The fourth phase (Methane Phase) is characterized by the production of methane and carbon dioxide: this production brings to a decrease of $\mathrm{pH}$ values and consequently to a decrease of metals concentration in the leachate.

In the last phase (Final Maturation), the biogas production gradually decreases, while methane and carbon dioxide concentrations keep constant. 
Am. J. Engg. \& Applied Sci., 1 (4): 393-398, 2008

Table 1: Typical biogas composition

\begin{tabular}{ll}
\hline Compound & {$[\%]$} \\
Methane & 47.5 \\
Carbon dioxide & 47.0 \\
Nitrogen & 3.7 \\
Oxygen & 0.8 \\
Paraffinic Hydrocarbons & 0.1 \\
PAH & 0.2 \\
Hydrogen & 0.1 \\
Hydrogen sulfate & 0.01 \\
Carbon monoxide & 0.1 \\
Traces compounds & 0.5 \\
Parameters & Value \\
Temperature & $41^{\circ} \mathrm{C}$ \\
Heat potential & Less than $17.727 \mathrm{~kJ} \mathrm{~m}^{-3}$ \\
Density & $1.04 \mathrm{~kg} \mathrm{~m}^{-3}$ \\
Moisture & Saturated \\
\hline
\end{tabular}

The most important features due to landfill management and closure are biogas and leachate production. These features become more important if the landfill is old or uncontrolled, as there are not always bottom sealing and leachate and biogas collection systems. In these cases, emissions from the landfill body can constitute a real hazard for the environment.

Biogas is essentially made of methane $\left(\mathrm{CH}_{4}\right)$, carbon dioxide $\left(\mathrm{CO}_{2}\right)$ and Nitrogen (Table 1). Especially methane concentration is worrying, as it is a very powerful greenhouse gas and its greenhouse power is 23 times higher than $\mathrm{CO}_{2}$. Moreover, methane is explosive or inflammable if its concentration varies between the $5 \%$ and the $15 \%$ b.v. in the air. Therefore, if the gas collection system is inappropriate or missing, biogas can leak from landfill and cumulate in the soil beneath the buildings, causing powerful explosions.

The leachate production is another important issue due to landfill management.

Leachate characteristics like $\mathrm{pH}, \mathrm{COD}$ and ammonia nitrogen varies during the landfill life (Table 2). Leachate reaches its most pollutant condition during the acid phase, while it stabilizes during the methanogenic phase.

In situ aeration of the landfill leads to a switch from anaerobic to aerobic degradation of the organic substances. Aerobic processes transform the organic substance into $\mathrm{CO}_{2}$ and $\mathrm{H}_{2} \mathrm{O}$, thus avoiding $\mathrm{CH}_{4}$ and illsmelling compounds formation.

Even leachate characteristics change due to the aerobic stabilization: TOC, $\mathrm{BOD}_{5}$ and $\mathrm{COD}$ parameters decrease and $\mathrm{NH}_{4}{ }^{+}$decreases, too.

The aerobic biodegradation is much faster than anaerobic one and it can lead to biological stability in a very short time. Through this process, the volume of the landfill is reduced and environmental impacts are stopped.
Table 2: Typical leachate composition

\begin{tabular}{|c|c|c|c|c|}
\hline \multirow[t]{2}{*}{ Parameter } & \multicolumn{2}{|c|}{ ACID Phase } & \multicolumn{2}{|c|}{ Methanogenic phase } \\
\hline & $\begin{array}{l}\text { Mean } \\
\left(\mathrm{mg} \mathrm{L}^{-1}\right)\end{array}$ & $\begin{array}{l}\text { Range } \\
\left(\mathrm{mg} \mathrm{L}^{-1}\right)\end{array}$ & $\begin{array}{l}\text { Mean } \\
\left(\mathrm{mg} \mathrm{L}^{-1}\right)\end{array}$ & $\begin{array}{l}\text { Range } \\
\left(\mathrm{mg} \mathrm{L}^{-1}\right)\end{array}$ \\
\hline $\mathrm{pH}$ & 6.10 & $4.5-7.5$ & 8 & $7.5-9$ \\
\hline $\mathrm{BOD}_{5}$ & 13000.00 & $4000-40000$ & 180.00 & $20-550$ \\
\hline COD & 22000.00 & $6000-60000$ & 3000.00 & $500-4500$ \\
\hline $\begin{array}{l}\text { BOD }_{5} / \\
\text { COD (adim.) }\end{array}$ & 0.58 & - & 0.06 & - \\
\hline $\mathrm{SO}_{4}^{--}$ & 500.00 & $70-1750$ & 80.00 & $10-420$ \\
\hline $\mathrm{Ca}$ & 1200.00 & $10-2500$ & 60.00 & $20-600$ \\
\hline $\mathrm{Mg}$ & 470.00 & $50-1150$ & 180.00 & $40-350$ \\
\hline $\mathrm{Fe}$ & 780.00 & $20-2100$ & 15.00 & $3-280$ \\
\hline $\mathrm{Mn}$ & 25.00 & $0.3-65$ & 0.70 & $0.03-45$ \\
\hline $\mathrm{Zn}$ & 5.00 & $0.1-120$ & 0.60 & $0.03-4$ \\
\hline $\mathrm{Sr}$ & 7.00 & $0.5-15$ & 1.00 & $0.3-7$ \\
\hline
\end{tabular}

Therefore, in situ aeration of landfill can solve environmental problems due to biogas and leachate production and can lead to economic advantages, as post-closure times are strongly reduced ${ }^{[5]}$.

The aerobic biodegradation effectiveness depends on several parameters, which must be carefully monitored, in order to have information about the proceeding status. The main parameters are the following:

- Oxygen concentration: If $\mathrm{O}_{2}$ concentration is too low, the degradation slows down. Even if a minimum concentration of the $5 \%$ b.v. in the air can be acceptable, the optimum conditions are with oxygen concentrations higher than the $10 \%$ b.v.

- Temperature: Temperature values during aerobic biodegradation are higher than during anaerobic one and they can reach $50-60^{\circ} \mathrm{C}$. In some cases temperature can even reach $80^{\circ} \mathrm{C}$ and the microbial activity is limited. In controlled situation the optimum temperature values are into the mesophilic range $\left(15-40^{\circ} \mathrm{C}\right)$

- Moisture: the aerobic biodegradation process requires high quantity of water, in order to guarantee the microbial activity and to lower the temperature values. Microbial activity stops under a $15 \%$ b.w. moisture value, but the optimum values are between the $45 \%$ and the $65 \%$ b.w. In fact, below the $45 \%$ b.w., the activity of bacteria is too slow, while above the $65 \%$ water fills the voids and the oxygen diffusion is limited

- $\mathrm{pH}$ : the waste aerobic biodegradation is not strongly linked to $\mathrm{pH}$ values, due to the variety of bacterial families into the waste mass. Optimum $\mathrm{pH}$ values are between 6.5 and 8 , but the biodegradation can take place even for values between 5.5 and 9 


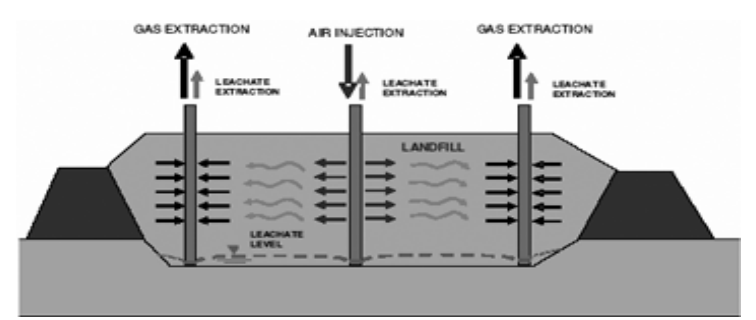

Fig. 2: Typical plant scheme

The typical plant scheme of the aeration of landfills (Fig. 2) is made of injection and extraction devices. Air can be injected at low or high pressures and in continuous or impulsive mode, the extraction flow is usually at least the $30 \%$ higher than injection one, in order to prevent the natural migration of biogas to the atmosphere and ensure the complete collection of gas from the landfill.

The extracted gas must be treated before being released in the atmosphere and the most common treatment systems used in these cases are the biofilters.

Some patented systems of air injection into the landfill have been developed in the last years, like the Biopuster $^{\circledR}$, AEROflott $^{\circledR}$ or AirFlow systems.

Some case studies and their aims or results are listed below:

Biopuster $^{\odot}$ applications:

- Fischer Landfill (2002-2006)

- Contaminated Site Wiener Neudorf (2002running)

- Kiener Landfill (1999-2000)

- Landfill Pontedera (1999)

The aim of these projects has been the odour stabilization and safety control before displacement of the wastes.

AEROflott $^{\circledR}$ application:

- $\quad$ Kuhstedt Landfill, Germany (2001-2003)

- After two years of aeration, $\mathrm{CH}_{4}$ concentration was lower than $3 \%$ b.v. and $\mathrm{CO}_{2}$ concentration was lower than $5 \%$ b.v. in the extracted gas. Moreover, a $5 \%$ volume reduction was measured

AirFlow application:

- Modena Landfill, Italy (2003-2005)

The landfill was aerated in order to prevent risks and facilitate the waste displacement. After two years,
$\mathrm{CH}_{4}$ concentration was lower than the $2 \%$ and $\mathrm{CO}_{2}$ lower than the $7 \%$ in the extracted gas. A significant leachate reduction was measured in the lower part of the deposit.

\section{MATERIAL AND METHODS}

In order to evaluate the feasibility of an in situ aeration of landfill, the biological stability of the wastes is one of the most important parameters that must be considered.

The biological stability can be defined as the optimal condition for the growth of the microbial populations, where biodegradation processes are extremely slowed down.

A variety of methods are available to evaluate the biological stability of the waste. The most common ones used in Italy are:

- Total Volatile Solids determination,

- Potentially Fermentable Solids Determination,

- Respirometric methods,

- Residual biogas production methods,

- Distilled $\mathrm{H}_{2} \mathrm{O}$ cession test

- Black Index determination.

Depending on the applied method, stability conditions are shown in Table 3.

If the wastes are biologically stable, the aeration of the landfill is not necessary. On the other hand, if stability conditions are below the measured values, the aerobic biodegradation can be applied in order to obtain stability and minimize the environmental impact of the landfill.

In March 2006, the biological stability of the wastes coming from the Trinitapoli Landfill, Italy, has been evaluated.

The landfill is located in Puglia, in the south-est of Italy and has been closed in 1996. The volume of the landfill is about $1,000,000 \mathrm{~m}^{3}$ and the average waste thickness is about $4 \mathrm{~m}$. The top of the aquifer is about one meter below the bottom of the landfill, that is characterized by high hydraulic conductivity values, moreover, the landfill is destitute of bottom sealing and biogas and leachate collection systems, so a possible instability of the wastes could cause a real hazard for the environment.

In order to evaluate the biological stability of the landfill, samples have been taken in four different points of the landfill and Black Index Test and Static Respirometric Index Test have been performed on that samples. 
Am. J. Engg. \& Applied Sci., 1 (4): 393-398, 2008

Table 3: Stability values for each test

\begin{tabular}{ll}
\hline Method & Stability condition \\
\hline Volatile Total Solids determination & $\mathrm{STV}<8 \%$ \\
Static Respirometric Index & $\mathrm{IRS}<180-200 \mathrm{mgO}_{2} / \mathrm{kgST} \mathrm{IR}_{4}<5 \mathrm{mgO}_{2} / \mathrm{gST} \mathrm{IR}_{7}<9 \mathrm{mgO}_{2} / \mathrm{gST}$ \\
Dynamic Respirometric Index & $\mathrm{IRD}<1000 \mathrm{mgO}_{2} / \mathrm{kgSV}$ \\
Residual biogas production methods & $\mathrm{GB}_{21}<20 \mathrm{Nl} / \mathrm{kgST} \mathrm{GS}_{90}<20 \mathrm{Nl} / \mathrm{kgST}$ \\
Distilled $\mathrm{H}_{2} \mathrm{O}$ cession test & $\mathrm{BOD}_{5} / \mathrm{COD}<0.2 \mathrm{BOD}_{5} / \mathrm{COD}<0.1 \mathrm{e} \mathrm{COD}<1500 \mathrm{mg} \mathrm{L}$ \\
Black Index determination & Low BI \\
\hline
\end{tabular}

Black index test: The Black Index (BI) is a parameter created by the Padua University in order to evaluate the possible instability of the wastes. The index measures $\mathrm{H}_{2} \mathrm{~S}$ produced by the wastes in anaerobic conditions, by means of a lead acetate paper that becomes black in the presence of $\mathrm{H}_{2} \mathrm{~S}$ due to lead sulphide formation:

$$
\left(\mathrm{CH}_{3} \mathrm{COO}\right)_{2} \mathrm{~Pb}+\mathrm{H}_{2} \mathrm{~S} \rightarrow 2 \mathrm{CH}_{3} \mathrm{COOH}+\mathrm{PbS}
$$

The $\mathrm{BI}$ is a defined as $1 / \mathrm{t}$, where $\mathrm{t}$ is the blackening time of the paper.

If the paper becomes black in a short time (a few hours), that indicates a sure instability of the wastes. If the paper becomes black in a long time or it doesn't become black, that indicates a possible stability of the waste, in this case, however, the lack of blackening of the paper can be relative to a lack of sulphur into the waste.

Black Index evaluation can be only used as a preliminary test and it must be followed by a more specific test, like Static Respirometric Index or Dynamic Respirometric Index determination.

In order to evaluate the Black Index for the wastes from Trinitapoli landfill, 60 grams samples ( 1 for each point of sampling) have been put into glass vials, along with lead acetate paper and they have been sealed with parafilm.

The test lasted for 7 days and no paper blackening have been noticed. This showed a possible biological stability of the wastes, so a Static Respirometric Index Test has been performed to have a more specific evaluation.

Static respirometric index test: The static Respirometric Index (SRI) indicates the oxygen consumption due to the organic matter biodegradation.

The instrumentation used to perform the test is made of six $1 / 2$ litre bottles, with a cap where is located an alkaline trap. The bottles are linked to a manometer.

The bacterial activity consumes the oxygen contained into the wastes and produces carbon dioxide, which is captured by the alkaline trap, this leads to a pressure decrease into the bottle that is measured by the manometer. The pressure decrease is relative to the oxygen consumption, so the manometer shows the oxygen consumed by the bacteria on a graduated scale. The oxygen consumption is referred to the weight of total solids of the waste sample, so the measure unit of $\mathrm{SRI}$ is $\mathrm{mgO}_{2} / \mathrm{kgTS} \cdot \mathrm{h}$.

Samples have been prepared by adding a quantity of water in order to reach a $55 \%$ b.w. moisture value. The alkaline trap is made of $\mathrm{KOH}$ granules.

Each one of the four samples has been divided into four parts, for a total of 16 samples of about $100 \mathrm{gm}$ each. 16 tests have been performed and each one lasted for $72 \mathrm{~h}$.

\section{RESULTS AND DISCUSSION}

The results of the Static Respirometric Index Test are shown in Fig. 3.

Mean values of SRI for samples S1, S2, S3, S4 (Table 4) show that for sample $\mathrm{S} 1$ the maximum biological activity is noticed. Anyway, all the values are below the limit value indicated by the guidelines (200 $\left.\mathrm{mgO}_{2} / \mathrm{kgTS} \cdot \mathrm{h}\right)$.

Although all the value of SRI are below the limit values, it is possible to know how much biogas may be still produced by correlating SRI values to potential biogas production. A first correlation can be established between $\mathrm{AT}_{4}\left[\mathrm{gO}_{2} / \mathrm{kgDM}\right]$ and $\mathrm{B}_{21}\left[\mathrm{Nl}_{\text {biogas }} / \mathrm{kgDM}\right]$, where:

- $\mathrm{AT}_{4}$ is the (static) respiration activity after 4 days

- $\mathrm{DM}$ is the dry matter $(\mathrm{DM}=\mathrm{TS})$

- $\mathrm{B}_{21}$ is the potential biogas production measured in a 21 days test

Converting SRI values of sample S1 into $\mathrm{AT}_{4}$ values, $B_{21}$ values can be estimated by means of the following correlation (Fig. 4):

$$
\begin{aligned}
\mathrm{SRI}(\mathrm{S} 1) & =116.4 \mathrm{mgO}_{2} / \mathrm{kgTS} \cdot \mathrm{h} \rightarrow \mathrm{AT} 4=11.136 \mathrm{gO}_{2} / \mathrm{kgTS} \\
\mathrm{B} 21 & =4.47 \mathrm{AT} 4-1.18 \rightarrow \mathrm{B} 21=48.6 \text { Nlbiogas } / \mathrm{kgTS}
\end{aligned}
$$

The biogas potential production after 21 days can give an indication about aerobic bacterial activity, but the total potential production can be estimated only by 


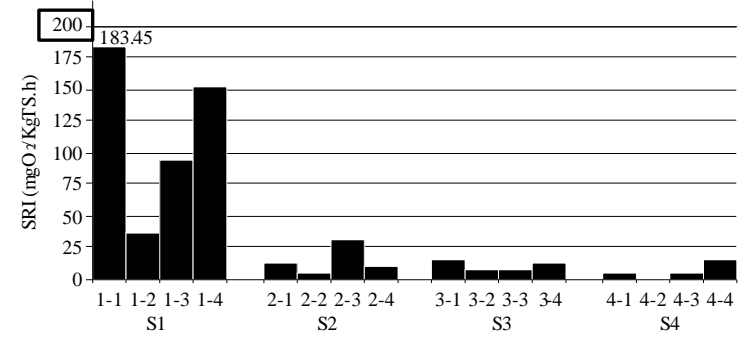

Fig. 3: SRI test results

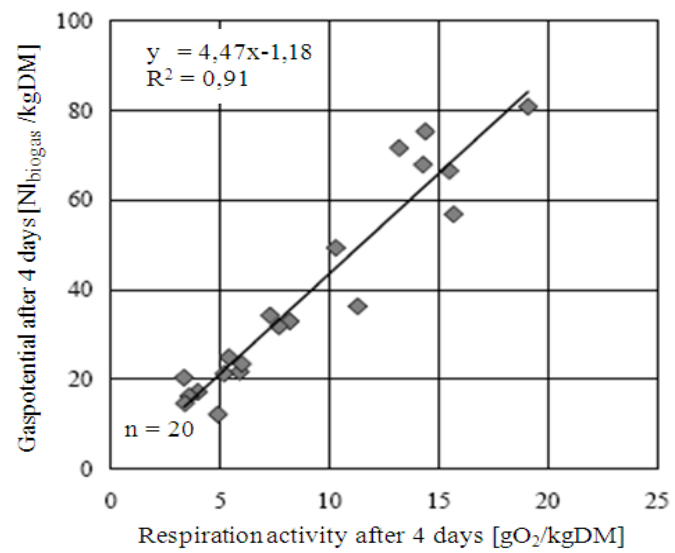

Fig. 4: Correlation between $\mathrm{AT}_{4}$ and $\mathrm{B}_{21}{ }^{[3,4]}$

Table 4: SRI mean values

\begin{tabular}{ll}
\hline Sample & $\mathrm{SRI}_{\text {mean }}\left(\mathrm{mgO}_{2} / \mathrm{kgTS} . \mathrm{h}\right)$ \\
\hline S1 & 116,4 \\
$\mathrm{~S} 2$ & 14,7 \\
$\mathrm{~S} 3$ & 10,5 \\
$\mathrm{~S} 4$ & 6,2 \\
\hline
\end{tabular}

means of longer tests (90 or 240 days). A second correlation can be established between the biogas potential production after 21 days and after 240 days:

By means of the correlation shown in Fig. 5, a biogas potential production after 90 days $\left(\mathrm{GS}_{90}\right)$ of about $94 \mathrm{Nl}_{\text {biogas }} / \mathrm{kgTS}$ can be estimated.

The total biogas potential production by the wastes can be expressed by means of the potential production after 240 days, $\mathrm{GS}_{240}$. For $\mathrm{GS}_{90}$ values higher than $30 \mathrm{Nl}_{\text {biogas }} / \mathrm{kgTS}$, the potential production represents the $95 \%$ of the total biogas production $\left(\mathrm{GS}_{240}\right)$. Assuming this comparison ${ }^{[1,2]}$, a total biogas potential production of $98,94 \mathrm{Nl}_{\text {biogas }} / \mathrm{kg}$ TS can be estimated.

It is now possible to estimate the biogas production by the wastes of the sample S1 part of the landfill. Considering an area of about $50 \times 50 \mathrm{~m}$ (Fig. 6) and assuming a mean depth of $4 \mathrm{~m}$, the volume of wastes is about $10000 \mathrm{~m}^{3}$. Knowing that the mean moisture value in this area of the landfill is the $15 \%$ b.w. and assuming

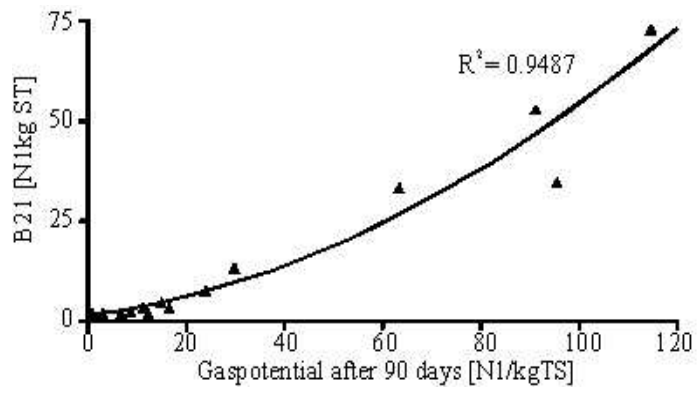

Fig. 5: Correlation between $\mathrm{B}_{21}$ and $\mathrm{GS}_{90}$ (Binner et al., 1999)

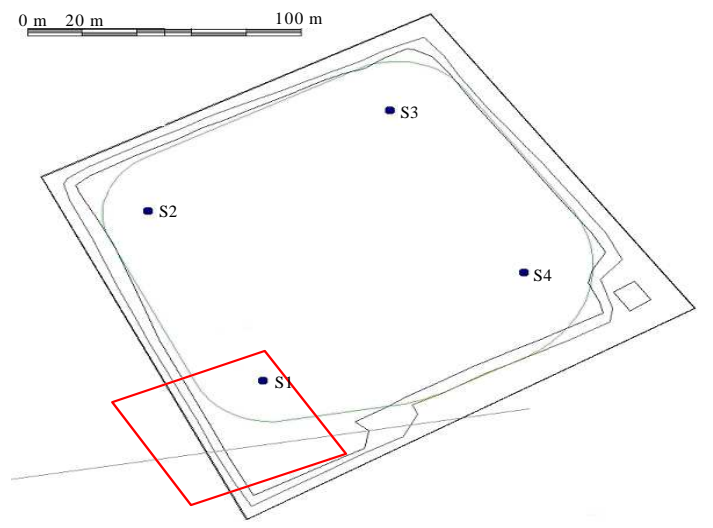

Fig. 6: Area of sample S1 in Trinitapoli Landfill

that the density of the wastes is $800 \mathrm{~kg} \mathrm{~m}^{-3}$ a Total Solids content of $6800 \mathrm{t}$ can be estimated.

The total biogas production can be estimated as following:

Biogas potential production $=98.94 \mathrm{Nm}^{3} / \mathrm{tST}$.

$$
6800 \mathrm{tST}=672792 \mathrm{Nm}_{\text {biogas }}^{3}
$$

\section{CONCLUSSION}

This is an estimation of the total biogas that may be still produced by the wastes in the area of sample S1, it can be useful to have a first evaluation of potential risks connected to biogas leak and methane concentrations.

In order to have a more precise value of the biogas potential production several tests can be performed, like fermentation or incubation tests.

\section{REFERENCES}

1. APAT, 2005. Digestione anaerobica della frazione organica dei rifiuti solidi-Aspetti fondamentali, progettuali, gestionali, di impatto ambientale ed integrazione con la depurazione delle acque reflue, Manuali e linee guida, 13/2005. 
2. APAT, 2003. Metodi di misura della stabilità biologica dei rifiuti, Manuali e linee guida, 25/2003.

3. Cossu, R., R. Raga and D. Rossetti, 2005. Fullscale application of aerobic in situ stabilization of an old landfill in North Italy, in Sardinia 2005. Proceeding of the 10th International Symposium on Waste Management and Landfill Symposium, Oct. 3-7, S. Margherita di Pula, Cagliari.

4. Heerenklage J. and R. Stegmann, 2005. Analytical methods for the determination of the biological stability of waste samples, in Sardinia 2005. Proceeding of the 10th International Symposiumon Waste Management and Landfill Symposium, Oct. 3-7, S. Margherita di Pula, Cagliari.
5. Ritzkowski M., K.U. HEYER and R. Stegmann, 2003. In situ aeration of old landfills: carbon balances, temperatures and settlements, in Sardinia 2003. Proceeding of the 9th International Symposium on Waste Management and Landfill, Oct. 6-10, S. Margherita di Pula, Cagliari. 